\title{
Nutrient limitation of bacteria and sources of nutrients supporting nutrient-limited bacterial growth in an Amazonian floodplain lake
}

\author{
Danny Rejas ${ }^{1,2, *}$, Koenraad Muylaert ${ }^{3}$, Luc De Meester ${ }^{1}$ \\ ${ }^{1}$ Laboratory of Aquatic Ecology, Katholieke Universiteit Leuven, Debériotstraat 32, 3000 Leuven, Belgium \\ ${ }^{2}$ Unidad de Limnología y Recursos Acuáticos, Universidad Mayor de San Simón, casilla 471, Cochabamba, Bolivia \\ ${ }^{3}$ Section Protistology \& Aquatic Ecology, Department of Biology, University Gent, Krijgslaan 281 - S8, 9000 Gent, Belgium
}

\begin{abstract}
Laguna Bufeos is a white-water floodplain lake located in the upper Amazon basin (Ichilo River, Bolivia). To study nutrient limitation of bacteria and to determine the sources supporting nutrient-limited bacterial growth, 5 nutrient deletion/dilution experiments were carried out in Laguna Bufeos. We carried out 3 experiments during 3 consecutive low-water seasons and 2 experiments during 1 high-water season. No evidence of $\mathrm{N}$ or $\mathrm{P}$ limitation was observed during the 2 experiments in the high-water season. Conversely, bacteria were limited by $\mathrm{P}$ in the 3 experiments in the low-water season. Limitation by $\mathrm{N}$ occurred only in one of the low-water experiments. Nutrientlimited bacterial growth rates equaled 37 to $86 \%$ of nutrient-saturated growth rates. Nutrients recycled by microzooplankton, mainly heterotrophic nanoflagellates and oligotrich ciliates, were the major nutrient source supporting P- or N-limited growth. Our results suggest a strong control of bacterial growth rates by P in Amazonian white-water lakes during the low-water season, while this limitation is alleviated during the high-water season, probably through supply of new nutrients from the river. The strong nutrient limitation of bacteria and the dependence of bacteria on nutrients supplied by their predators can be expected to slow down the decomposition of organic matter in Amazonian floodplain lakes. This may partly explain why these ecosystems are often rich in organic matter.
\end{abstract}

KEY WORDS: White water · Amazon · Floodplain lake $\cdot$ Bacteria $\cdot$ Nutrient limitation $\cdot$ Phosphorus Nutrient deletion/dilution experiments

\section{INTRODUCTION}

As the C:N and C:P ratios of bacterial cells are usually substantially lower than those of the organic matter they use as a substrate, heterotrophic bacteria are usually dependent on external, inorganic sources of nutrients (Caron et al. 1988, Fenchel et al. 1998). Several studies have shown that when external concentrations of inorganic nutrients are low, inorganic nutrients may limit the growth of planktonic bacteria (Toolan et al. 1991, Coveney \& Wetzel 1992). Phosphorus (P) is often the major inorganic nutrient limiting bacterial growth (Thingstad et al. 1998, Vrede et al. 1999), although nitrogen $(\mathrm{N})$ limitation has also been observed in some studies (Torréton et al. 2000, Sala et al. 2002). Even in ecosystems where phytoplankton is N-limited, bacteria have been found to be limited by P (Vrede et al. 1999). $\mathrm{P}$ limitation of bacterial growth has been observed in marine (Thingstad et al. 1998, Pinhassi \& Berman 2003) as well as freshwater (Sterner et al. 1995, Vrede et al. 1999, Pinhassi \& Berman 2003) ecosystems.

Since its discovery, the microbial loop has been assumed to play a major role in the recycling of nutrients in aquatic ecosystems (Azam et al. 1983, Porter et al. 1985). Given the poor nutrient content of the organic substrates of bacteria, protozoans may be expected to be more important nutrient remineralizers than bacteria (Caron et al. 1988, Fenchel et al. 1998). When bacteria are nutrient-limited, protozoans may not only cause mortality to bacteria through grazing, but may 
also stimulate their growth by supplying remineralized nutrients (Chrzanowski et al. 1995, Sterner et al. 1995). Nutrient deletion/dilution experiments provide an excellent tool for determining the importance of recycled nutrients in sustaining bacterial growth; they are based on the dilution method developed by Landry \& Hassett (1982) for studying microzooplankton grazing on phytoplankton. The dilution method was later extended to study microzooplankton grazing on bacteria by Tremaine \& Mills (1987). The nutrient deletion/dilution technique is an extension of this method, developed by Andersen et al. (1991) to study the contribution of external, internal and recycled nutrients in supporting growth of nutrient limited phytoplankton. The technique was applied to study nutrient-limitation of bacteria in an oligotrophic lake in Canada (Sterner et al. 1995), but since then has (to our knowledge), never been used again to study the sources of nutrients supporting nutrient-limited bacteria.

Amazonian ecosystems are generally nutrient-poor systems (Hill \& Rai 1982, Furch \& Junk 1997). Several recent studies suggest that $P$ is the main limiting nutrient for bacteria in Amazonian lakes and rivers (Farjalla et al. 2002a,b, Castillo et al. 2003, Rejas et al. in press). Amazonian rivers have been classified into 3 types (Sioli 1984). Black- and clear-water rivers are poor in nutrients and suspended matter. While the former are coffee-coloured and often acidic due to high concentrations of humic acids, clear-water rivers have a high water transparency and a near-neutral pH. Whitewater rivers are generally richer in nutrients and suspended matter and have a low water transparency. Floodplain lakes of white-water rivers are named 'várzea lakes'. These várzea lakes are linked with the main river during the annual high-water season or flood pulse. This flood pulse is of vital importance for the functioning of várzea lakes (Hamilton \& Lewis 1987). During the flood pulse, the lakes receive high inputs of nutrients and organic matter from the river and the surrounding forests. During the low-water season, floodplain lakes are isolated from the river, and nutrient concentrations in the lakes become rapidly depleted (Rai \& Hill 1984a, Thomaz et al. 1992).

The goal of this study was to study nutrient limitation of bacteria in Laguna Bufeos, a várzea lake situated along the Ichilo River in the upper Amazon basin. A previous study of this lake had demonstrated that bacteria are sometimes strongly P limited (Rejas et al. in press). Using nutrient deletion/dilution experiments we aimed at evaluating the role of microzooplankton as remineralizers of nutrients in this tropical lake. Experiments were carried out during the low- as well as the high-water season to evaluate in what way the flood pulse might affect bacterial nutrient limitation in várzea lakes.

\section{MATERIALS AND METHODS}

Study site. The experiments were carried out in Laguna Bufeos, a floodplain lake in the Ichilo River basin, situated in the tropical lowlands of Bolivia $\left(16.43^{\circ} \mathrm{S}\right.$ to $\left.64.70^{\circ} \mathrm{W}\right)$. This lake was chosen because of its pristine status-it is not directly influenced by human activities. The only access to the site is by boat via the Ichilo River, a 1 d trip from the closest village accessible by road. The lake is situated $174 \mathrm{~m}$ above sea level in a tropical zone. Mean annual air temperatures exceed $25^{\circ} \mathrm{C}$ and annual precipitation is about 2000 to $2500 \mathrm{~mm}$. Temperature variations are generally small, although subantarctic winds occasionally result in a sharp drop in air temperature down to $14^{\circ} \mathrm{C}$. Laguna Bufeos has a surface area of 80 ha. The mean depth of the lake is approximately $2.30 \mathrm{~m}$ during the low-water season and $4.30 \mathrm{~m}$ during the high-water season (Maldonado et al. 1996). Flooding of the lake is related to the water level of the Ichilo River, which corresponds with the dry (July to September) and rainy seasons (October to June). Due to its proximity to the headwaters of the Andes Cordillera, however, local precipitation events can result in sudden increases in the water level of the river. During these short events, river water may flow into the lake through a connecting channel. The water level of the Ichilo River displays an annual fluctuation of up to $9 \mathrm{~m}$ and usually peaks in February (Fig. 1).

Surface lake-water temperature varies between 26 and $33^{\circ} \mathrm{C}$. Wind induced mixing of the water-column precludes water column stratification, although a weak thermal gradient may develop during warm and calm days, with a maximum of $3^{\circ} \mathrm{C}$ difference between surface and bottom lake water. Due to high concentrations of inorganic and organic suspended matter the lake water in Laguna Bufeos is very turbid, with a mean Secchi depth of only $0.6 \mathrm{~m}$. Inorganic nutrient concentrations in the lake are low. In a monitoring study (Rejas et al. in press), soluble reactive phosphorus concentrations were usually below the detection limit of the nutrient analysis system used $(0.15 \mu \mathrm{M})$ while $\mathrm{NO}_{3}$ concentrations ranged between 1.5 and $3 \mu \mathrm{M}$. Chlorophyll a concentrations vary between 5 and $10 \mu \mathrm{g} \mathrm{l}^{-1}$ during the low-water season and between 7 and $13 \mu \mathrm{g} \mathrm{l}^{-1}$ during the high-water season. The nano- and microphytoplankton community is dominated by Chlorophyta and Chrysophyta (Ayala et al. 2003). The lake also contains high densities of cyanobacterial picophytoplankton ( 3 to $30 \times 10^{5}$ cells $\mathrm{ml}^{-1}$ ). As in many other várzea lakes (Thomaz et al. 1992), particulate (3 to $4 \mathrm{mg} \mathrm{l}^{-1}$ ) and dissolved $\left(\approx 10 \mathrm{mg} \mathrm{l}^{-1}\right)$ organic carbon concentrations are relatively high. Particulate organic matter concentrations are high relative to chlorophyll a concentration, sug- 


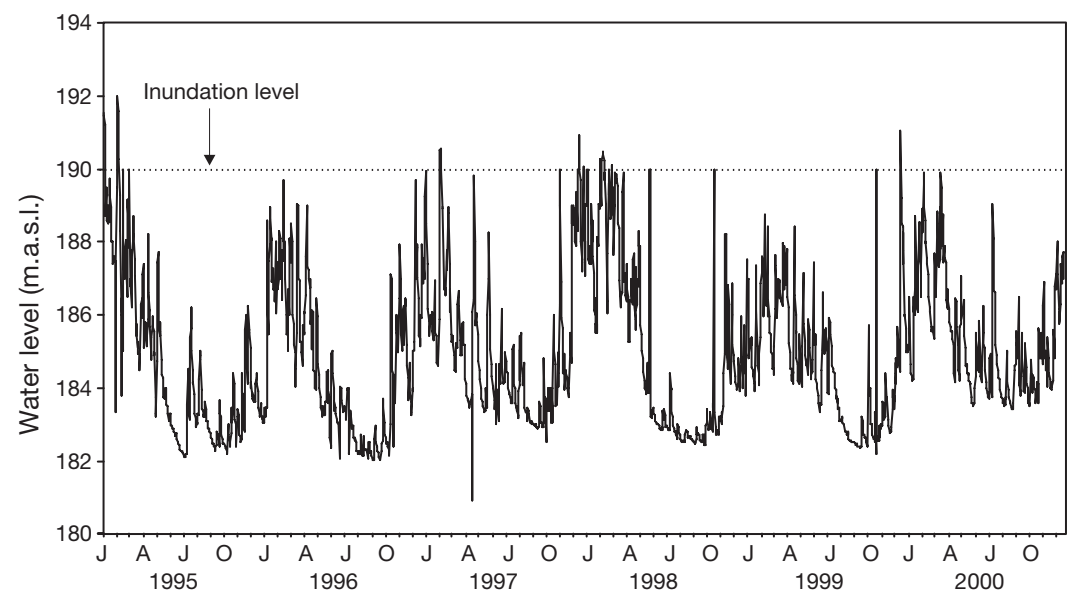

Fig. 1. Hydrological regime of River Ichilo at Puerto Villarroel, $50 \mathrm{~km}$ upstream of Laguna Bufeos (data from Bolivian Army). m.a.s.l.: meters above sea level

gesting important allochthonous sources of organic matter. Bacterioplankton abundance in Laguna Bufeos ranges between 2 and $10 \times 10^{6}$ cells $\mathrm{ml}^{-1}$ (Rejas et al. 2002). The zooplankton community is composed of rotifers (Brachionus spp. and Polyarthra spp.), small cladocerans (Moina minuta and Bosminopsis deitersi) and cyclopoid copepods (predominantly young stages: Acosta et al. unpubl. data).

Experimental design. We used the approach of Andersen et al. (1991) to evaluate whether bacteria in Laguna Bufeos were nutrient-limited and, if nutrient limitation occurred, to estimate the role of external, internal and recycled nutrients in supporting growth of nutrient-limited bacteria. In dilution experiments, water containing prey as well as predators is diluted with filtered water that is free of prey and predators. As a result of the dilution, contact rates between prey and predator are reduced and therefore net growth rate of the prey organisms should increase linearly with increasing dilution. Linear regression of net growth rates against dilution allows estimation of the maximal growth rate in the absence of predators and the predation rates. Growth rate $\mu$ is equal to the intercept with the $y$-axis, while the grazing rate $g$ is equal to the slope of the regression line. This method has 3 important assumptions: (1) gross growth rates of the prey organisms are independent of dilution, (2) grazing impact is a linear function of prey abundance, and (3) prey growth rates are exponential (Landry \& Hassett 1982). When nutrients are limiting, the first assumption is unlikely to be met. More nutrients will be available per prey organism in the most diluted treatments, which may result in higher gross growth rates in diluted treatments. Alternatively, supply of nutrients recycled by grazers will be higher in the least-diluted treatments, which may result in higher gross growth rates. Differences in nutrient concentra- tions between different dilutions are avoided by adding nutrients in non-limiting concentrations to all dilutions.

Andersen et al.'s (1991) extension to the dilution method makes use of the fact that nutrient supply rates may differ with dilution to estimate the contribution of different sources of nutrients supporting growth of nutrient-limited prey items. In their approach, in addition to a dilution series whereby all dilutions receive nutrients in non-limiting concentrations, extra dilution series are incubated where the limiting nutrient(s) are deleted one at a time. The dilution series receiving the full nutrient additions is used to determine the grazing rate. This grazing rate-which is dependent on the dilution - is used to correct the observed growth rates for grazing losses of the other dilution series. Regression of these grazing-corrected net growth rates against dilution allows evaluation of the relative importance of external nutrients, internal nutrient reserves and nutrients recycled by the predators in supporting growth of nutrient-limited prey organisms. If grazing-corrected growth rates are higher in the undiluted treatments, this indicates that recycled nutrients are important. If grazing-corrected growth rates are higher in the more diluted treatments, this indicates that external nutrient sources are more important. Support of growth by internal nutrient reserves is independent of dilution.

Experimental setup. We carried out 5 experiments in Laguna Bufeos, 3 during the low-water season (October 23, 2000: LW1; August 21, 2001: LW2; August 22, 2002 : LW3) and 2 during the high-water season (April 19, 2001: HW1; April 23, 2001: HW2). For all experiments, a 201 integrated sample of the top $1.5 \mathrm{~m}$ of the water column was collected with a tube sampler in a fixed station in the centre of the lake. The water was immediately screened through a $200 \mu \mathrm{m}$ pore-size nylon mesh to remove mesoand macrozooplankton. About half of this water was filtered through $0.22 \mu \mathrm{m}$ pore-size polycarbonate membrane filters. These filters were assumed to retain bacteria and their predators but to leave concentrations of dissolved substances unaltered. During Expt LW1, filtration through $0.22 \mu \mathrm{m}$ filters reduced bacterial densities to $0.07 \%$ of the natural densities in lake water and heterotrophic nanoflagellate (HNF) densities to undetectable levels. 200 and $0.22 \mu \mathrm{m}$ filtrates were mixed to achieve 5 target dilution levels containing approximately $10,20,50,80$ and $100 \%$ of $200 \mu$ m filtered water. The actual dilution level $x$ (expressed as the fraction of $200 \mu \mathrm{m}$-filtered water) was empirically determined by comparing initial bacterial counts at each dilution level to bacterial counts at the $200 \mu \mathrm{m}$ filtrate. 
Water from each dilution level was distributed over 6 (9 for undiluted water) transparent $60 \mathrm{ml}$ polycarbonate bottles (Fig. 2); 2 bottles of each dilution level and 3 bottles of undiluted water received a complete nutrient addition, consisting of $35 \mu \mathrm{M}$ nitrogen $(\mathrm{N})$ in the form of $\mathrm{NH}_{4} \mathrm{Cl}$ and $7 \mu \mathrm{M}$ phosphorus (P) in the form of $\mathrm{KH}_{2} \mathrm{PO}_{4}$. To study $\mathrm{N}$ and $\mathrm{P}$ limited growth, 2 bottles from each dilution level (3 bottles of undiluted water) received only $\mathrm{N}$ or only $\mathrm{P}$, respectively. In one of the experiments (LW1), we also tested whether carbon limited bacterial growth. Water from each dilution level was distributed over 8 bottles (12 of undiluted water); 2 bottles from each dilution level (3 of undiluted water) received a complete nutrient addition, consisting of $\mathrm{N}$, $\mathrm{P}$ and glucose $\left(0.2 \mathrm{mg} \mathrm{l}^{-1}\right)$ as a carbon source. To study $\mathrm{N}$-, P- and C-limited growth, 2 bottles from each dilution level (3 bottles of undiluted water) received only $\mathrm{P}$ and $\mathrm{C}$, only $\mathrm{N}$ and $\mathrm{C}$ or only $\mathrm{N}$ and $\mathrm{P}$, respectively. In all experiments, 3 replicates of each nutrient treatment were used for the $100 \%$ undiluted $200 \mu \mathrm{m}$ filtrate, since nutrient limitation was evaluated in these treatments.

The 33 bottles (44 for Expt LW1) were incubated for $24 \mathrm{~h}$ in the lake under natural light and temperature conditions at a depth of about $30 \mathrm{~cm}$. For determination

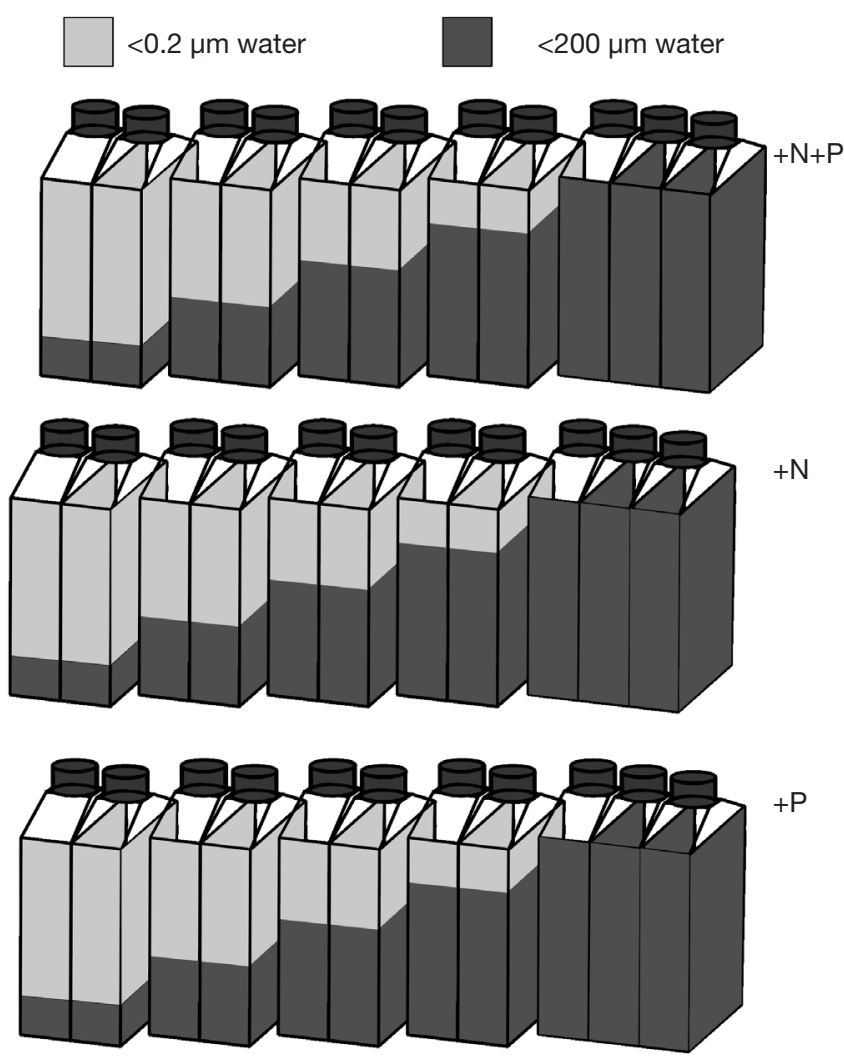

Fig. 2. Experimental setup for Expts LW2, LW3, HW1 and HW2 (in Expt LW1, an extra dilution series was included to test for limitation by organic carbon) of bacterial abundance, duplicate $15 \mathrm{ml}$ samples were collected from each bottle at the start and at the end of the experiments. Samples were fixed with $0.2 \mu \mathrm{m}$ filtered formaldehyde (3\% final concentration) and stored at $4^{\circ} \mathrm{C}$ in the dark. Samples for determining HNF and ciliate abundance were collected at the start of the experiments from the $200 \mu \mathrm{m}$ filtrate. We fixed $100 \mathrm{ml}$ samples according to the Lugol-formalinthiosulphate method (Sherr \& Sherr 1993).

Analysis of samples. Bacteria were stained with DAPI and filtered onto black $0.2 \mu \mathrm{m}$ pore-size polycarbonate filters (Sherr et al. 1993) within 1 mo of collection. Using epifluorescence microscopy, at least 200 bacteria sample ${ }^{-1}$ were counted in a minimum of 10 random fields. HNF were also stained with DAPI and counted using epifluorescence microscopy, but were filtered onto $0.8 \mu \mathrm{m}$ pore-size filters (Sherr et al. 1993). On average, 100 cells were counted along at least 10 random transects across the filter. We switched to blue light excitation to distinguish heterotrophic from autotrophic flagellates. Ciliates were counted using inverted microscopy. The samples were stained with Bengal Rose $\mathrm{B}$ to aid in distinguishing living cells from detrital material. On average, 50 cells were counted along a minimum of 10 transects. Given the low number of ciliates that were counted, ciliate densities should be interpreted with care. All ciliate samples were analyzed within 2 mo of collection.

Data analysis. Net bacterial exponential growth rates $\left(\mu_{\text {net, }}\right.$ in $\left.\mathrm{d}^{-1}\right)$ were calculated from initial and final bacterial densities as $\mu_{\text {net }}=\ln \left(C_{t} / C_{0}\right) \cdot 1 / t$, where $C_{0}$ and $C_{t}$ are abundances of bacteria at the start and the end of the experiment, respectively, and $t$ is the incubation time in days. Data from the dilution series receiving the full set of nutrients were used to determine the maximal bacterial growth rate in the absence of predators $\left(\mu_{\max }\right)$, and bacterial grazing losses $(g)$. Both $\mu_{\max }$ and $g$ were estimated from the linear regression of $\mu_{\text {net }}$ against the dilution factor $(x)$.

To evaluate whether bacteria were nutrient-limited, grazing-corrected bacterial growth rates in the undiluted water were compared by means of a 1-way ANOVA with Scheffé's post-hoc test. Net growth rates were corrected for grazing losses $\left(\mu^{\prime}\right)$ according to the formula $\mu^{\prime}=\mu_{\text {net }}+g \cdot x$. In this formula, $g$ is the grazing rate estimated from bacterial growth rates in the dilution series receiving the full enrichment and the dilution factor $x$ is equal to 1 in undiluted water. When grazing-corrected bacterial growth rates in the undiluted water were significantly lower in the treatments that lacked either $\mathrm{N}, \mathrm{P}$ or $\mathrm{C}$ than in the treatments receiving the full enrichment, this was considered to be indicative of limitation. In this case, we analyzed the data of all dilution levels, correcting net growth rates for grazing losses using the formula outlined above. 
The contribution of internal and external nutrient pools as well as nutrients recycled by microzooplankton to nutrient-limited bacterial growth was assessed by means of the regression model developed by Andersen et al. (1991): $\mu=\ln \left(1+K_{\mathrm{r}} \cdot x+K_{\mathrm{i}}+K_{\mathrm{e}} / x\right) \cdot 1 / t$. In this model, $K_{\mathrm{r}}$ is the production coefficient associated with recycled nutrients, $K_{\mathrm{i}}$ is the production coefficient due to internal nutrient stores and $K_{\mathrm{e}}$ is the production coefficient due to external nutrients. Negative coefficients were forced to zero to allow only models that were biologically realistic (Sterner et al. 1995). The software program Statistica was used to carry out the non-linear regression.

\section{RESULTS}

Environmental conditions in the lake at the time of the experiments are summarized in Table 1. Water-column depth varied more than $1 \mathrm{~m}$ between the highwater and low-water seasons. Water temperature was about $5^{\circ} \mathrm{C}$ lower during Expts HW2 and LW3 due to a sudden drop in air temperature caused by Antarctic winds. Conductivity was higher during the high-water season than the low-water season, probably because of water inflow from the Ichilo River mainstem, which shows higher conductivity than the lake (D. Rejas unpubl. data). pH varied between 6.1 and 7.3 and did not differ consistently between high- and low-water seasons. Secchi depth tended to be higher during the high-water season, probably because of reduced wind and/or fish-induced resuspension of bottom sediments due to the deeper water column. Bacterial densities in the lake water at the start of the experiments varied between $1.38 \times 10^{6}(\mathrm{LW} 2)$ and $9.15 \times 10^{6} \mathrm{cells} \mathrm{ml}^{-1}$ (HW1). HNF densities varied between 356 (LW2) and 3224 (LW3) cells $\mathrm{ml}^{-1}$, and ciliate densities between 36 (LW1) and 763 (LW3) cells ml ${ }^{-1}$. The HNF community was dominated by free-living forms varying between
5 and $15 \mu \mathrm{m}$ in size, while the ciliate community was dominated by oligotrich ciliates of 30 to $50 \mu \mathrm{m}$. No data for HNF and ciliates are available for the HW1 and HW2 experiments, so we cannot conclude whether protozoan densities differed between the high- and low-water season.

The linear regression of net growth rates against the dilution factor in the dilution series with complete nutrient enrichment revealed a linear decline in net growth rates with increasing dilution factor in all experiments (Fig. 3). From the regression, we estimated the maximum attainable growth rates $\mu_{\max }$ (i.e. growth rates in the absence of grazers and nutrient limitation) and the rate of grazing losses $g$ due microzooplankton grazing. Maximum growth rates $\mu_{\max }$ were lower in Expts HW2 and LW3 $\left(0.86 \mathrm{~d}^{-1}\right.$ and $1.06 \mathrm{~d}^{-1}$, respectively) than in the other experiments (1.60 to $2.12 \mathrm{~d}^{-1}$ ), possibly due to the lower temperatures at the time of Expts HW2 and LW3. The highest grazing losses $g$ were observed in Expt LW3 $\left(2.11 \mathrm{~d}^{-1}\right)$ and coincided with highest HNF and ciliate densities. The lowest grazing losses were observed in Expt LW1 $\left(0.75 \mathrm{~d}^{-1}\right)$ (Table 2).

To test for nutrient limitation, grazing-corrected bacterial growth rates in the undiluted water were compared between treatments receiving the full enrichment and treatments receiving all nutrients except one (Fig. 4). No significant differences were observed between the nutrient treatments in the high-water season experiments.

In the low-water experiments, where nutrient limitation was observed, the contributions of internal, external and recycled nutrients to nutrient-limited bacterial growth rates were estimated (Fig. $5 \&$ Table 3 ). The full model including $K_{\mathrm{i}}, K_{\mathrm{e}}$ and $K_{\mathrm{r}}$ resulted in high $\mathrm{R}^{2}$ values for the non-linear regression. However, it resulted in negative regression coefficients, which is biologically unrealistic. Therefore, we forced negative coefficients to equal zero, which resulted in lower $\mathrm{R}^{2}$ values

Table 1. Water-column conditions at time of the experiments. October 2000, August 2001 and August 2002 represent low-water (LW) season, April 2001 represents high-water (HW) season. HNF: heterotrophic nanoflagellates

\begin{tabular}{|c|c|c|c|c|c|}
\hline Parameter & LW1 & HW1 & HW2 & LW2 & LW3 \\
\hline Date & Oct 23, 2000 & Apr 19, 2001 & Apr 23, 2001 & Aug 21, 2001 & Aug 22, 2002 \\
\hline Water temperature $\left({ }^{\circ} \mathrm{C}\right)$ & $31.8-33.0$ & $31.4-31.7$ & $26.4-27.1$ & $31.3-31.7$ & $25.5-26.1$ \\
\hline Oxygen $\left(\mathrm{mg} \mathrm{l}^{-1}\right)$ & $5.7-6.8$ & $5.9-6.8$ & $5.9-7.0$ & $7.9-8.0$ & $5.5-5.8$ \\
\hline $\mathrm{pH}$ & $6.2-6.5$ & $6.1-6.3$ & $6.1-6.3$ & $7.1-7.3$ & 6.3 \\
\hline Conductivity $\left(\mu \mathrm{S} \mathrm{cm}^{-1}\right)$ & 61 & 90 & 91 & 60 & 67 \\
\hline Secchi depth $(\mathrm{cm})$ & 48 & 87 & 73 & 66 & 71 \\
\hline Depth $(\mathrm{m})$ & 2.00 & 3.15 & 3.15 & 2.20 & 2.15 \\
\hline Bacteria (cells ml ${ }^{-1}$ ) & $4.57 \times 10^{6}$ & $9.15 \times 10^{6}$ & $6.67 \times 10^{6}$ & $1.38 \times 10^{6}$ & $7.21 \times 10^{6}$ \\
\hline$\pm \mathrm{SD}(\mathrm{n}=3)$ & $\pm 5.00 \times 10^{3}$ & $\pm 2.06 \times 10^{6}$ & $\pm 1.13 \times 10^{6}$ & $\pm 4.71 \times 10^{4}$ & $\pm 7.68 \times 10^{4}$ \\
\hline $\mathrm{HNF}\left(\right.$ cells $\left.\mathrm{ml}^{-1}\right) \pm \mathrm{SD}(\mathrm{n}=2)$ & $847 \pm 232$ & - & - & $356 \pm 117$ & $3224 \pm 438$ \\
\hline Ciliates $\left(\right.$ cells ml $\left.{ }^{-1}\right) \pm S D(n=2)$ & $36 \pm 12$ & - & - & $42 \pm 9$ & $763 \pm 126$ \\
\hline
\end{tabular}


but yielded models that were biologically realistic (cf. Sterner et al. 1995). In all low-water experiments, where nutrient limitation of bacteria occurred, grazing-corrected growth rates were highest in the leastdiluted water. In all experiments where phosphorus limitation occurred, P recycled by microzooplankton was the major P source supporting bacterial growth. In Expts LW1 and LW3, it was the only P source supporting P limited bacterial growth. In Expt LW2, recycled as well as external $P$ sources significantly supported bacterial growth, although recycled $\mathrm{P}$ was much more important than external sources. In Expt LW3, where N was also limiting, the only significant source of $\mathrm{N}$ was $\mathrm{N}$ recycled by microzooplankton. Internal reserves $\left(K_{\mathrm{i}}\right)$ of $\mathrm{P}$ or $\mathrm{N}$ never contributed significantly to bacterial growth in any experiment.

\section{DISCUSSION}

Since its development more than 20 yr ago, the dilution method has increasingly been used to study growth rates and grazing losses of phytoplankton (e.g. Calbet \& Landry 2004). Nevertheless, the results of
Table 2. Maximum growth rate $\left(\mu_{\max }\right)$ and grazing rates $(g)$ $( \pm \mathrm{SE})$ calculated from linear regression on dilution series with complete nutrient enrichment. $\mathrm{R}^{2}$ : coefficient of determination for regression; $\mathrm{n}$ : number of observations

\begin{tabular}{|lcccr|}
\hline Expt & $\mu_{\max }( \pm \mathrm{SE})$ & $g( \pm \mathrm{SE})$ & $\mathrm{R}^{2}$ & $\mathrm{n}$ \\
\hline LW1 & $1.62( \pm 0.25)$ & $0.75( \pm 0.31)$ & 0.39 & 11 \\
HW1 & $1.60( \pm 0.13)$ & $1.45( \pm 0.19)$ & 0.87 & 11 \\
HW2 & $0.86( \pm 0.10)$ & $0.83( \pm 0.16)$ & 0.74 & 10 \\
LW2 & $2.12( \pm 0.07)$ & $1.40( \pm 0.10)$ & 0.96 & 9 \\
LW3 & $1.06( \pm 0.18)$ & $2.11( \pm 0.25)$ & 0.89 & 11 \\
\hline
\end{tabular}

dilution experiments should be interpreted cautiously as, in specific cases, some assumptions of the method may be invalid. The assumption that is most likely to be violated is the proportional decline in grazing pressure with increasing dilution level. In the case of threshold or saturated feeding, grazing pressure may not be linearly related to the dilution level (e.g. Gallegos 1989). Moreover, predator growth rates may be higher in undiluted than in highly diluted water due to lower food concentrations in diluted water (e.g. Dolan et al. 2000). This may result in an overestimation of grazing rates (Dolan \& McKeon 2004). Threshold or
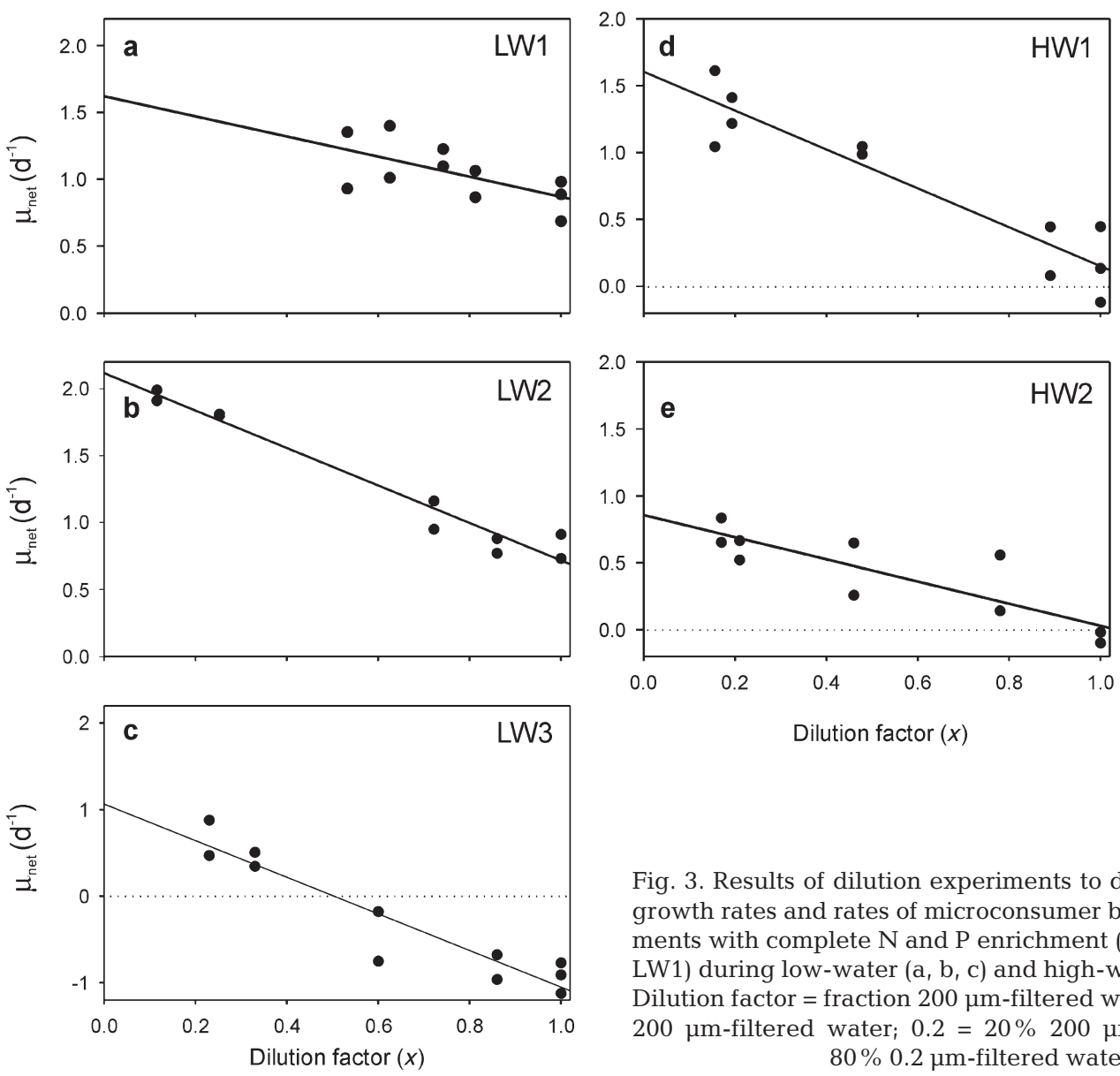

Fig. 3. Results of dilution experiments to determine bacterial growth rates and rates of microconsumer bacterivory in treatments with complete $\mathrm{N}$ and $\mathrm{P}$ enrichment ( $\mathrm{N}, \mathrm{P}$ and $\mathrm{C}$ in Expt LW1) during low-water $(\mathrm{a}, \mathrm{b}, \mathrm{c})$ and high-water $(\mathrm{d}, \mathrm{e})$ seasons. Dilution factor $=$ fraction $200 \mu \mathrm{m}$-filtered water (e.g. $1=100 \%$ $200 \mu \mathrm{m}$-filtered water; $0.2=20 \% 200 \mu \mathrm{m}$-filtered water + $80 \% 0.2 \mu \mathrm{m}$-filtered water) 

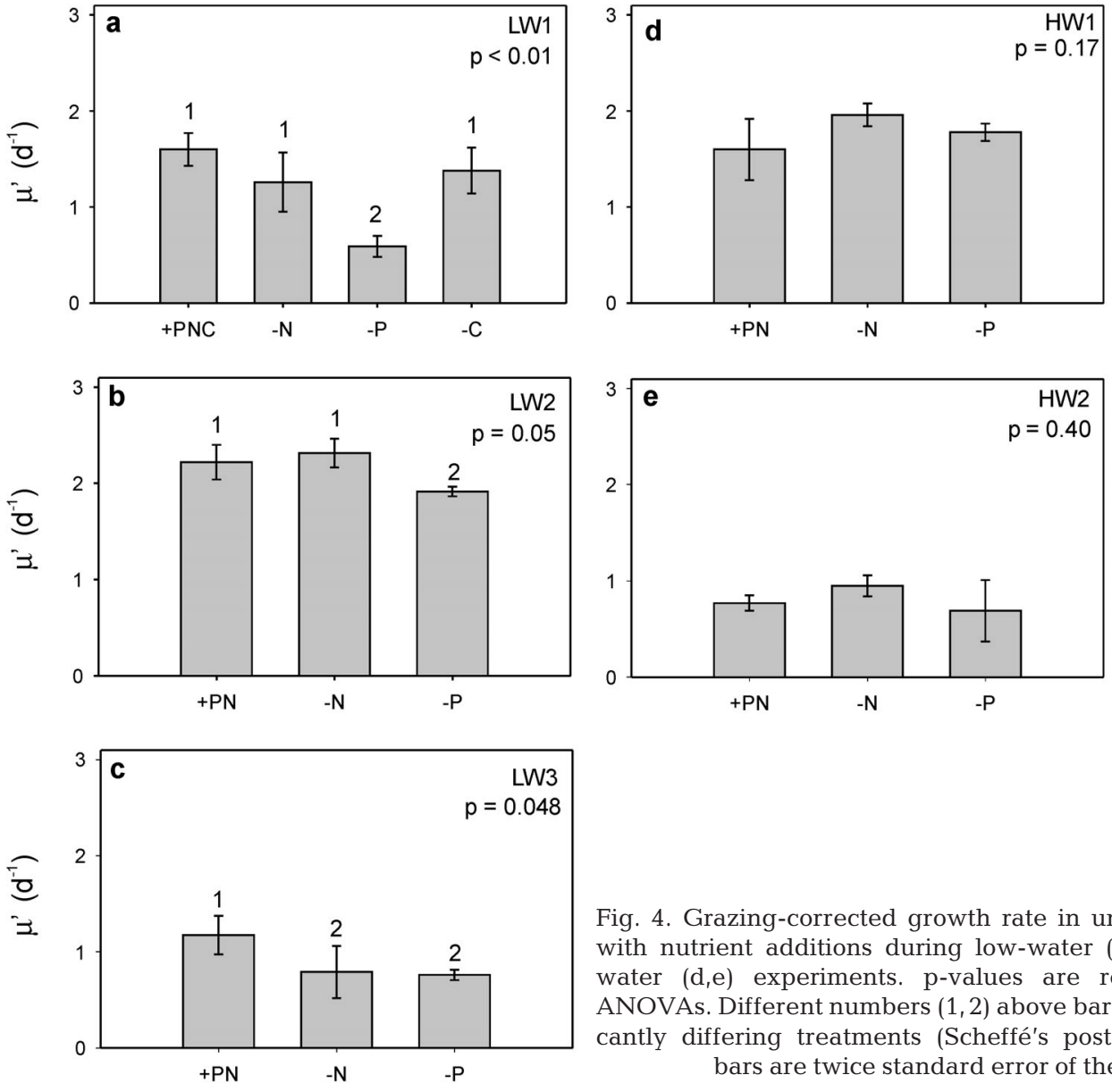

Fig. 4. Grazing-corrected growth rate in undiluted samples with nutrient additions during low-water $(a, b, c)$ and highwater $(d, e)$ experiments. p-values are results of 1-way ANOVAs. Different numbers $(1,2)$ above bars indicate significantly differing treatments (Scheffé's post-hoc test). Error bars are twice standard error of the mean

Fig. 5. Grazing-corrected growth rate responses to dilution factor in dilution series without $\mathrm{P}$ addition $(\mathrm{a}, \mathrm{b}, \mathrm{C}$, for experiments in which $\mathrm{P}$ limitation occurred), and without $\mathrm{N}$ addition $(\mathrm{d}$, for the one experiment in which $\mathrm{N}$ limitation occurred). Dilution factor as in Fig. 3
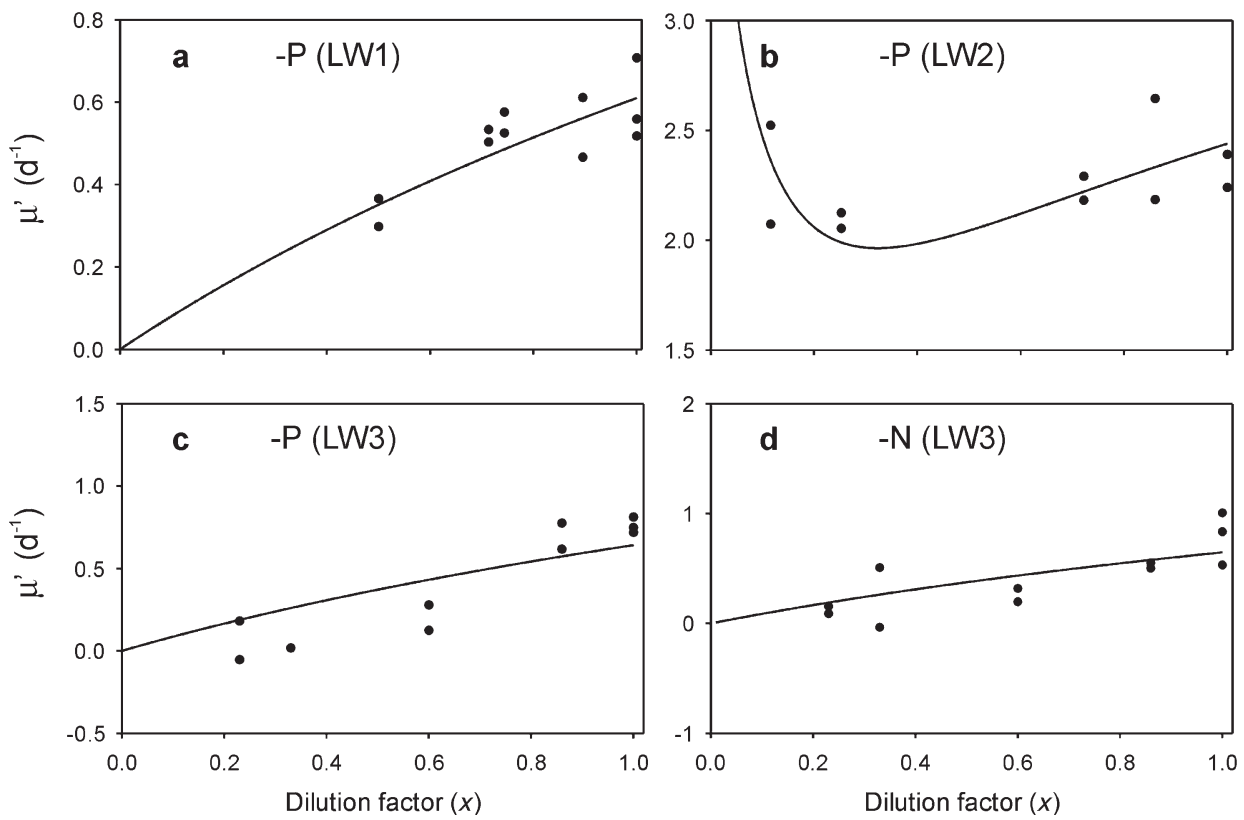
Table 3. Potential production coefficients for recycled $\left(K_{\mathrm{r}}\right)$, internal $\left(K_{\mathrm{i}}\right)$ and external $\left(K_{\mathrm{e}}\right)$ supplies of $\mathrm{P}$ and $\mathrm{N}$, estimated from multiple regression for experiments in which limiting nutrient limitation occurred. Only significant coefficients are shown

\begin{tabular}{|cccccc|}
\hline Expt & Nutrient & $K_{\mathrm{r}}$ & $K_{\mathrm{i}}$ & $K_{\mathrm{e}}$ & $\mathrm{R}^{2}$ \\
\hline LW1 & $\mathrm{P}$ & 0.84 & - & - & 0.78 \\
LW2 & $\mathrm{P}$ & 9.47 & - & 0.99 & 0.34 \\
LW3 & $\mathrm{P}$ & 0.90 & - & - & 0.70 \\
LW3 & $\mathrm{N}$ & 0.91 & - & - & 0.59 \\
\hline
\end{tabular}

saturated feeding responses can often be detected visually in the plots of apparent growth rate versus dilution level. In our experiments, the linear relation between apparent growth rates of bacteria and dilution level suggests that no threshold or saturated feeding occurred (Fig. 3). To avoid violation of the assumption that predation declines proportionally with increasing dilution level, Landry et al. (1995) proposed estimating microzooplankton grazing pressure at different dilution levels by monitoring the disappearance of labeled prey cells in the incubation bottles. Dolan et al. (2000) proposed monitoring microzooplankton densities in the incubation bottles during the course of the experiment. Both extensions of the dilution method would have been difficult to apply in Laguna Bufeos because of the high concentrations of suspended matter in the lake. The high suspended-matter concentrations would preclude the use of a flow cytometer, which is used in the approach of Landry et al. (1995). High suspended-matter concentrations also make enumeration of microzooplankton in all treatments very tedious and time-consuming.

The assumptions for using dilution experiments with bacteria have been tested by Tremaine \& Mills (1987), and dilution experiments have been used previously to study bacterial growth and grazing rates and bacterial nutrient limitation (Sterner et al. 1995). Because the sources of carbon (e.g. phytoplankton) are affected by dilution, growth rates of bacteria may be influenced not only by grazing but also by carbon limitation. We tested and did not observe C limitation in Laguna Bufeos, therefore we think dilution experiments are appropriate for studying bacterial grazing loses and nutrient limitation in the lake.

Dilution experiments with full substrate additions were used to determine maximum bacterial growth rates and microzooplankton grazing rates in Laguna Bufeos. Although we did not systematically test for the influence of temperature on maximum bacterial growth rates, our results indicate that maximum growth rates were lower at 25.5 to $27.1^{\circ} \mathrm{C}$ than at 31.3 to $33.0^{\circ} \mathrm{C}$. This drop in temperature occurred during experiments in the low-water season (LW3) of 2002 and the high- water season (HW2) of 2001. These results indicate that also in tropical ecosystems, naturally occurring changes in temperature may significantly influence bacterial growth rates. Our results also suggest that microzooplankton grazing rates were highest when the highest densities of HNF and ciliates were observed. It should be noted, however, that data on grazer abundances were lacking for the 2 high-water experiments.

Limitation of bacteria by substrates was tested by comparing bacterial growth rates in a dilution series lacking a given substrate with growth rates in the dilution series receiving full substrate additions. Limitation of bacterial growth by organic matter was only tested during the first experiment (LW1), which was carried out during the low-water season of 2000. In this experiment, no evidence for carbon limitation was observed. Given the high concentrations of organic matter in Laguna Bufeos in particular and in várzea lakes in general, carbon was not expected to be limiting in Laguna Bufeos. Moreover, in the upper reaches of the Amazon basin, where Laguna Bufeos is situated, a larger fraction of the organic matter is bioavailable than in the lower reaches (Hedges et al. 2000). No information on carbon limitation is available for the high-water season. However, as várzea lakes receive large amounts of organic matter from the surrounding forest during the flood pulse (Junk et al. 1989, Benner et al. 1995), carbon limitation is less likely during the high-water than during the low-water season.

In contrast to the first experiment, the subsequent experiments focused only on limitation by inorganic nutrients. Our results indicate that nutrients, especially $\mathrm{P}$, limited bacterial growth rates during the low-water but not during the high-water season. In the 3 experiments carried out during 3 consecutive low-water seasons, bacterial growth was repeatedly found to be stimulated by $\mathrm{P}$ additions. Grazing-corrected bacterial growth rates in undiluted lake water receiving no $\mathrm{P}$ addition were $37 \%$ of maximum bacterial growth rates in Expt LW1, 86\% during Expt LW2 and 65\% during Expt LW3. In Expt LW3, N addition produced a further stimulation of bacterial growth rate in addition to $\mathrm{P}$, indicating co-limitation of $\mathrm{N}$ and $\mathrm{P}$. In this experiment, grazing-corrected bacterial growth rates in undiluted lake water lacking $\mathrm{N}$ were $67 \%$ of the maximum bacterial growth rates. In contrast, no evidence was observed for $\mathrm{N}$ or $\mathrm{P}$ limitation in the 2 experiments carried out during the high-water season of 2001. In these experiments, ambient concentrations of both $\mathrm{N}$ and $\mathrm{P}$ supported bacterial growth rates similar to those in the nutrient-saturated treatments.

Because the 2 high-water experiments were carried out during the same high-water season, we should be careful in generalizing our conclusions regarding dif- 
ferences in nutrient limitation between the high- and low-water season. Nevertheless, the observed difference fits well with expectations from the flood-pulse theory (Junk 1997). Várzea lakes are dependent on the associated river as a source of inorganic nutrients. They receive inputs of inorganic nutrients during the flood pulse at the beginning of the high-water season (Payne 1986, Rai \& Hill 1984a, Thomaz et al. 1992). During the low-water season, concentrations of inorganic nutrients reach their minimum due to progressive dilution by rainwater and nutrient-poor surface runoff (Schmidt 1973), sedimentation, and utilization of nutrients by primary producers and subsequent transfer to higher trophic levels (Hamilton \& Lewis 1987). No nutrient measurements were carried out in Laguna Bufeos at the time of the experiments, but indirect evidence of the input of river water into the lake during the high-water season is provided by the relation between lake water level and conductivity. Conductivity in Laguna Bufeos (90 to $91 \mu \mathrm{S} \mathrm{cm}^{-1}$ ) was similar to that of the river (94 to $97 \mu \mathrm{S} \mathrm{cm} \mathrm{cm}^{-1}$ ) during the highwater season, but substantially lower than that of the river during the low-water season (60 to $67 \mu \mathrm{S} \mathrm{cm}^{-1}$ in Laguna Bufeos, 86 to $88 \mu \mathrm{S} \mathrm{cm}^{-1}$ in the river). Inputs of inorganic nutrients from the river during the highwater season thus probably explain the absence of nutrient limitation of bacterial growth in that season.

Our results are in agreement with those from a simple nutrient addition experiment carried out in Laguna Bufeos during the low-water season of 1998, where P but not $\mathrm{C}$ or $\mathrm{N}$ limited bacterial growth rates (Rejas et al. in press). Limitation of bacteria by inorganic nutrients or evidence thereof has been observed before in other Amazonian aquatic ecosystems. In black- and clear-water rivers of the Orinoco basin, Castillo et al. (2003) found strong P limitation of bacteria throughout the year, while $\mathrm{C}$ was only occasionally limiting. In experiments carried out during the high-water season in several clear-water lakes of the lower Amazon basin, Farjalla et al. (2002a) found that bacterial production was stimulated by $\mathrm{P}$ additions. In a monitoring study of white-water floodplain lakes of the upper Parana River, Carvalho et al. (2003) observed a higher bacterial abundance during the high-water season and ascribed this to inputs of nutrients and organic matter into the lakes by the flood pulse.

The parallel incubation of dilution series with and without addition of limiting nutrients allowed us to evaluate the sources of nutrients supporting nutrientlimited bacterial growth. Our results clearly show that when bacteria were nutrient-limited, nutrients recycled by microzooplankton were the major nutrient source supporting bacterial growth. In the LW1 experiment, data were available only for the region of high dilution factor (see Figs. 3a \& 5a), which may it make hard to detect the effect of external storage. However, the results from Expts LW2 and LW3 support those of Expt LW1. External nutrients played a role in only one experiment (LW2), and even then their contribution to bacterial growth was minimal compared to that of recycled nutrients. Internal sources never contributed significantly to nutrient-limited bacterial growth in any experiment. Our results thus indicate that in the absence of grazing little growth of bacteria would be possible, as external nutrients never significantly supported bacterial growth rates. In the presence of grazing microzooplankton represent an important cause of mortality to bacteria. However, at ambient grazer densities, bacteria attain growth rates that comprise 37 to $86 \%$ of the maximum achievable growth rate under nutrient-replete conditions. Bacteria can achieve these relatively high growth rates despite the near-absence of external nutrients thanks to the supply of remineralized nutrients by microzooplankton. In Laguna Bufeos, microzooplankton therefore cause mortality to bacteria, but are also a vital source of inorganic nutrients, mainly P. As no data are available to test the assumption that grazing rates on bacteria vary proportionally with the dilution level, grazing rates and nutrient remineralization rates by microzooplankton may have been overestimated in our study (Dolan \& McKeon 2004). Nevertheless, the contribution of other sources of nutrients to bacterial growth was never significant (for internal sources) or was 1 order of magnitude lower than that of recycled nutrients (for external sources). Therefore, our conclusion that recycled nutrients are the major nutrient source for bacteria is likely to be correct. From similar experiments carried out in an oligotrophic Canadian shield lake, Sterner et al. (1995) also concluded that recycled P was an important source of $\mathrm{P}$ supporting nutrient-limited bacterial growth, while internal sources where never significant. In their study, however, external sources of $\mathrm{P}$ were more important than in our study.

The fact that bacteria are P-limited and their dependence on nutrients recycled by their predators may have important implications for carbon cycling in várzea lakes, at least during the low-water season. Because of the high temperatures of tropical floodplain lakes, one would expect a rapid degradation of organic matter. However, organic matter concentrations are often very high in these lakes (Rai \& Hill 1984b, Thomaz et al. 1992, Farjalla 2002a,b), comparable to concentrations in eutrophic temperate ecosystems (Thurman 1985). The low availability of $P$ and the dependence of bacteria on $\mathrm{P}$ remineralized by their predators probably slows down the decomposition of organic matter in these lakes and may, in part, explain why organic matter concentrations remain so high. 
Acknowledgements. This study was financially supported by the Program for Institutional University Cooperation (IUC) between the Flemish Inter-University Council (VLIR) and the University Mayor de San Simón (UMSS). K.M. enjoys a post-doctoral grant from the Fund for Scientific Research, Flanders

\section{LITERATURE CITED}

Andersen TA, Schartau K, Paasche E (1991) Quantifying external and internal nitrogen and phosphorus pools, as well as nitrogen and phosphorus supplied through remineralization, in coastal marine plankton by means of a dilution technique. Mar Ecol Prog Ser 69:67-80

Ayala R, Rejas D, Declerck S (2003) Efectos de los peces sobre el fitoplancton de una laguna de várzea (laguna bufeos, Bolivia). Rev Bol Ecol Conserv 14:57-66

Azam F, Fenchel T, Field JG, Grey JS, Meyer-Reil LA, Thingstad $F$ (1983) The ecological role of water column microbes in the sea. Mar Ecol Prog Ser 10:257-292

Benner R, Opsal S, Chin-Leo G, Richey JE, Forsberg BR (1995) Bacterial carbon metabolism in the Amazon River system. Limnol Oceanogr 40:1262-1270

Berman T, Nawrocki M, Taylor GT, Karl DM (1987) Nutrient flux between bacteria, nanoplanktonic protists and algae. Mar Microb Food Webs 2:69-82

Calbet A, Landry MR (2004) Phytoplankton growth, microzooplankton grazing, and carbon cycling in marine systems Limnol Oceanogr 49:51-57

Caron D, Goldman J, Dennett M (1988) Experimental demostration of the roles of bacteria and bacterivorous protozoa in plankton nutrient cycles. Hydrobiologia 159: $27-40$

Carvalho P, Thomaz SM, Bini LM (2003) Effects of water level, abiotic and biotic factors on bacterioplankton abundance in lagoons of a tropical floodplain (Paraná River, Brazil). Hydrobiologia 510:67-74

Castillo MM, Kling GW, Allan JD (2003) Bottom-up controls on bacterial production in tropical lowland rivers. Limnol Oceanogr 48:1466-1475

Chrzanowski TH, Sterner RW, Elser JJ (1995) Nutrient enrichment and nutrient regeneration stimulate bacterioplankton growth. Microb Ecol 29:221-230

Coveney MF, Wetzel RG (1992) Effects of nutrients on specific growth rate of bacterioplankton in oligotrophic lake water cultures. Appl Environ Microbiol 58:150-156

Dolan JR, McKeon K (2004) The reliability of grazing rate estimates from dilution experiments: have we over-estimated rates of organic carbon consumption? Ocean Sci Discov $1: 21-36$

Dolan JR, Gallegos CL, Moigis A (2000) Dilution effects on microzooplankton in dilution grazing experiments. Mar Ecol Prog Ser 200:127-139

Farjalla VF, Esteves FA, Bozelli RL, Roland F (2002a) Nutrient limitation of bacterial production in clear water Amazonian ecosystems. Hydrobiologia 489:197-205

Farjalla VF, Faria BM, Esteves FA (2002b) The relationship between DOC and planktonic bacteria in tropical coastal lagoons. Arch Hydrobiol 156:97-119

Fenchel T, King GM, Blackburn TH (1998) Bacterial biogeochemistry: the ecophysiology of mineral cycling. Academic Press, San Diego, CA

Furch K, Junk W (1997) Physicochemical conditions in the floodplains. In: Junk W (ed) The central Amazon floodplain. Springer-Verlag, Berlin, p 69-108

Gallegos CL (1989) Microzooplankton grazing on phytoplank- ton in the Rhode River, Maryland-nonlinear feeding kinetics. Mar Ecol Prog Ser 57:23-33

Hamilton SK, Lewis WM (1987) Causes of seasonality in the chemistry of a lake on the Orinoco River floodplain, Venezuela. Limnol Oceanogr 32:1277-1290

Hedges JI, Mayorga E, Tsamakis E, McClain ME and 9 others (2000) Organic matter in Bolivian tributaries of the Amazon River: a comparison to the lower mainstream. Limnol Oceanogr 45:1449-1466

Hill G, Rai H (1982) A preliminary characterization of the tropical lakes of Central Amazon by comparison with polar and temperate systems. Arch Hydrobiol 96:97-111

Junk WJ (1997) General aspects of floodplain ecology with special reference to Amazonian floodplains. In: Junk WJ (ed) The central Amazon floodplain, ecology of a pulsing system. Springer-Verlag, Berlin, p 3-17

Junk WJ, Bayley PB, Sparks RE (1989) The flood pulse concept in river-floodplain systems. Can Spec Publ Aquat Sci 106:110-127

Landry MR, Hassett RP (1982) Estimating the grazing impact of marine microzooplankton. Mar Biol 67:283-288

Landry MR, Kirshtein J, Constaninou J (1995) A refined dilution technique for measuring the community grazing impact of microzooplankton, with experimental tests in the central equatorial Pacific. Mar Ecol Prog Ser 120:53-63

Maldonado M, Goitia E, Acosta F, Cadima M, Castellón D (1996) Caracterización limnológica de lagunas en la llanura aluvial del Río Ichilo, Cochabamba (Bolivia). Rev Bol Ecol Conserv 1:29-37

Payne AI (1986) The ecology of tropical lakes and rivers. John Wiley \& Sons, Chichester

Porter KG, Sherr EB, Sherr BF, Pace M, Sanders RW (1985) Protozoa in planktonic food webs. J Protozool 32:409-415

Rai H, Hill G (1984a) Primary production in the Amazonian aquatic ecosystem. In: Sioli H (ed) Amazon, limnology and landscape ecology of a mighty tropical river and its basin. W Junk, The Hague, p 311-336

Rai H, Hill G (1984b) Microbiology of Amazonian waters. In: Sioli H (ed) Amazon, limnology and landscape ecology of a mighty tropical river and its basin. W Junk, The Hague, p 413-442

Rejas D, Muylaert K, De Meester L (2002) Primeros datos sobre la comunidad microbiana en una laguna de várzea en la Amazonía boliviana (Laguna Bufeos, Cochabamba). Ecol Bol 37:51-63

Rejas D, Muylaert K, De Meester L (in press) Trophic interactions within the microbial food web in a tropical floodplain lake (Laguna Bufeos, Bolivia). Rev Biol Trop

Sala MM, Peters F, Gasol JM, Pedrós-Alió C, Marrasé C, Vaqué D (2002) Seasonal and spatial variations in the nutrient limitation of bacterioplankton growth in the northwestern Mediterranean. Aquat Microb Ecol 27:47-56

Schmidt GW (1973) Primary production of phytoplankton in the three types of Amazonian waters. II. The limnology of a tropical floodplain lake in central Amazonia (Lago Castanho). Amazoniana 4:139-203

Sherr EB, Sherr BF (1993) Preservation and storage of samples for enumeration of heterotrophic protists. In: Kemp PF, Sherr BF, Sherr EB, Cole JJ (eds) Handbook of methods in aquatic microbial ecology. Lewis, Boca Raton, FL, p 207-212

Sherr EB, Caron DA, Sherr BF (1993) Staining of heterotrophic protists for visualization via epifluorescence microscopy. In: Kemp PF, Sherr BF, Sherr EB, Cole JJ (eds) Handbook of methods in aquatic microbial ecology. Lewis, Boca Raton, FL, p 213-227

Sioli H (1984) The Amazon: limnology and landscape ecology 
of a mighty tropical river and its basin. W Junk, Dordrecht Sterner RW, Chrzanowski TH, Elser JJ, George NB (1995) Sources of nitrogen and phosphorus supporting the growth of bacterio- and phytoplankton in an oligotrophic Canadian shield lake. Limnol Oceanogr 40:242-249

Thingstad FT, Zweifel UL, Rassoulzadegan F (1998) P limitation of heterotrophic bacteria and phytoplankton in the northwest Mediterranean. Limnol Oceanogr 43:88-94

Thomaz S, Lansac-Toha F, Roberto M, Esteves F, Lima A (1992) Seasonal variation of some limnological factors of Lagoa do Guaraná, a várzea lake of the high Rio Paraná, state of Mato Grosso do Sul, Brazil. Rev Hydrobiol Trop 25: 269-276

Thurman EM (1985) Organic geochemistry of natural waters.

Editorial responsibility: Karl Šimek, Ceské Budéjovice, Czech Republic
Nijhoff \& Junk, Boston, MA

Toolan T, Wehr JD, Findlay S (1991) Inorganic phosphorus stimulation of bacterioplankton production in a mesoeutrophic lake. Appl Environ Microbiol 57:2074-2078

Torréton JP, Talbot V, Garcia N (2000) Nutrient stimulation of bacterioplankton growth in Tuamotu atoll lagoons. Aquat Microb Ecol 21:125-137

Tremaine S, Mills A (1987) Tests of the critical assumptions of the dilution method for estimating bacterivory by microeucaryotes. Appl Environ Microbiol 53:2914-2921

Vrede K, Vrede T, Isaksson A, Karlsson A (1999) Effects of nutrients (phosphorus, nitrogen, and carbon) and zooplankton on bacterioplankton and phytoplankton-a seasonal study. Limnol Oceanogr 44:1616-1624

Submitted: August 10, 2004; Accepted: January 3, 2005

Proofs received from author(s): April 1, 2005 